
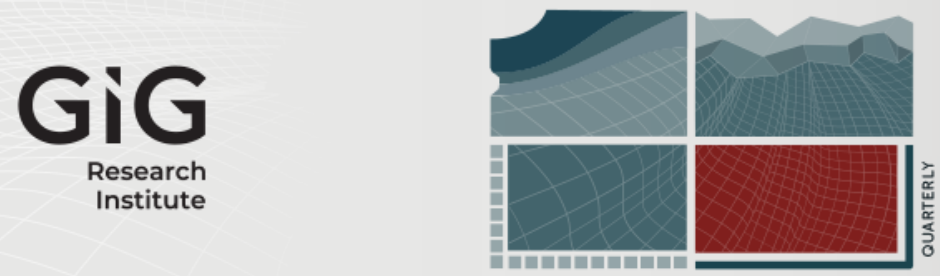

JOURNAL

OF

SUSTAINABLE

MINING

\title{
Gravity field changes during deep exploitation of the coal longwall and their relation to stress distribution and seismic activity
}

Author(s) ORCID Identifier:

Łukasz Kortas (D) 0000-0001-7276-0955

Follow this and additional works at: https://jsm.gig.eu/journal-of-sustainable-mining

Part of the Explosives Engineering Commons, Oil, Gas, and Energy Commons, and the Sustainability

\section{Commons}

\section{Recommended Citation}

Kortas, Łukasz (2021) "Gravity field changes during deep exploitation of the coal longwall and their relation to stress distribution and seismic activity," Journal of Sustainable Mining: Vol. 20 : Iss. 4 , Article 3.

Available at: https://doi.org/10.46873/2300-3960.1326

This Research Article is brought to you for free and open access by Journal of Sustainable Mining. It has been accepted for inclusion in Journal of Sustainable Mining by an authorized editor of Journal of Sustainable Mining. 


\title{
Gravity field changes during deep exploitation of the coal longwall and their relation to stress distribution and seismic activity
}

\begin{abstract}
Mining operations cause volumetric deformations within the rock mass and changes in its density, to which the gravimetric method is sensitive. These changes are particularly well seen in periodic measurements of the local gravity field. The paper analyses the relationship between the movement of a longwall in a coal seam and the change in the distribution of the gravity field in time and space observed on the ground surface. Relative gravimetric measurements were carried out in six series between 2018 and 2020; before the start of coal extraction, with the progress of the longwall and after the cessation of mining. Collected data allowed differential maps of changes in gravity to be plotted. Differential anomalies between the subsequent measurement series, and the reference one were then analysed. The distribution and temporal variations of the anomalies suggest a relationship between changes in density distribution of the rock medium in the longwall overburden, and the change in the stress state in the rock mass caused by the passage of the longwall front. An attempt was made to relate the variability of the state of stresses in the longwall overburden to the intensity of seismic tremors with energy $>10 \mathrm{E} 4 \mathrm{~J}$ accompanying longwall exploitation.
\end{abstract}

\section{Keywords}

gravity, mining, coal, seismicity, tremors

\section{Creative Commons License}

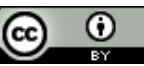

This work is licensed under a Creative Commons Attribution 4.0 License. 


\title{
Gravity field changes during deep exploitation of the coal longwall and their relation to stress distribution and seismic activity
}

\author{
Łukasz Kortas \\ Central Mining Institute (GIG), Department of Geology and Geophysics, Poland
}

\begin{abstract}
Mining operations cause volumetric deformations within the rock mass and changes in its density, to which the gravimetric method is sensitive. These changes are particularly well seen in periodic measurements of the local gravity field. The paper analyses the relationship between the movement of a longwall in a coal seam and the change in the distribution of the gravity field in time and space observed on the ground surface. Relative gravimetric measurements were carried out in six series between 2018 and 2020; before the start of coal extraction, with the progress of the longwall and after the cessation of mining. Collected data allowed differential maps of changes in gravity to be plotted. Differential anomalies between the subsequent measurement series, and the reference one were then analysed. The distribution and temporal variations of the anomalies suggest a relationship between changes in density distribution of the rock medium in the longwall overburden, and the change in the stress state in the rock mass caused by the passage of the longwall front. An attempt was made to relate the variability of the state of stresses in the longwall overburden to the intensity of seismic tremors with energy $>10 \mathrm{E} 4 \mathrm{~J}$ accompanying longwall exploitation.
\end{abstract}

Keywords: gravity, mining, coal, seismicity, tremors

\section{Introduction}

$\mathrm{U}$ nderground hard coal mining with longwall system in Upper Silesian Coal Basin in Poland (USCB) causes rock mass tremors [1-3] and the surface hazard of continuous and discontinuous deformations [4-8]. The part of the rock mass subject to exploitation and its overburden threatened by the occurrence of dynamic phenomena generate their own gravitational field whose change in time depends on the degree of threat [9]. Various geodynamic phenomena, including mining exploitation, cause volumetric deformations within the rock mass and changes in its density, to which the microgravimetric method is sensitive. These changes are observed by making periodic measurements of the local gravity field and analysing a picture of their changes in space and time [10-15]. In the overburden layers above the mine workings, particularly longwall workings, a dilatant change in density occurs as a result of momentary changes in the state of stress in areas of high stress concentration and in the absence of the possibility of deformation of the rock mass. It is positive when there is a temporary increase in stress and negative when there is a temporary state of relaxation.

In the research and forecasting of the development of dynamic phenomena in the exploited rock mass, the method of temporal changes of the gravity anomaly $g$ is successfully applied $[9,16]$. It consists in measuring the values of gravity at grid points distributed on the ground surface above the longwall in question at certain intervals. The differential anomalies between the next measurement series and the reference series, usually the first $g_{i+1}-g_{1}$ or between successive measurement series, are then analysed. In the latter case, the value measured at a given point in the earlier series is always subtracted from the value measured there in the later series, so that the distribution $g_{i+1}-g_{i}$ is examined.

Gravity measurements carried out in time series are aimed at the observation of changes in the 
gravitational field under the influence of the existence of zones of compaction and dilution in the rock medium in the overburden field. The appearance of these zones is the result of volumetric deformation of the rock mass occurring in the vicinity of the excavation under the influence of the mining activity. Centres with increased bulk density - densities, can be identified with the accumulation of elastic energy in their area, and dilatation zones where the bulk density locally decreases with places where the elastic energy has already been released or where it does not accumulate [9].

The subject of this article is to analyse the relationship between the movement of a longwall in the coal seam and the change in the distribution of the gravity field observed on the ground surface and caused by the extraction of coal by this longwall. Densification centres, i.e. differential positive anomalies, should be concentrated in the depleted part of the longwall where elastic energy accumulates after the longwall front passes through. The displacement of dilatation zones caused by the developing dilatancy process in the rock mass or zones of no density change should occur in the face of the longwall and near the plane of possible faults in their drop shoulders (densities in their hanging shoulders).

As the testing site the area directly above one of the deeply extracted coal longwall in USCB was selected. It is located in Rybnik-Niewiadom (Fig. 1) within the Rybnicki Okręg Węglowy (Rybnik Coal District - ROW) Coal Mine. In this part of the coal district, mining works are carried out by Mining Plant Rydułtowy.

In recent few years this particular area was one of the observation sites of the European Union research and development project called "European Plate Observing System" (EPOS) [17, 18] realized by Central Mining Institute (GIG) in Katowice, Poland. The test sites within this project ware called Multidisciplinary Upper Silesian Episodes and this particular one was designated as MUSE2.2.

The area of the chosen coal longwall called VIII E-E1 in seam 703/1 is of special interest due to the expected high environmental impact of the mining operations, including the forecasted high number of strong seismic tremors and significant surface subsidence in inhabited areas.

\section{Geological structure, tectonics and hydrogeological conditions}

The geological documentation of the deposit within the area of the Ryduttowy-Anna mine Mining Area Rydultowy-Anna [19] shows that the rock mass in the area of the Głowacki and Kościuszko shafts, where the MUSE2.2 surveying range is located, is made of Carboniferous formations covered by $10 \mathrm{~m}$ thick layer of Quaternary formations (sands, loamy and silty sands). Below, in the Kościuszko shaft, there is a layer of hard fine-grained sandstone with inserts of clay shale to the depth of about $15 \mathrm{~m}$ (Figs. 2 and 3). The arrangement of Carboniferous strata is illustrated by a fragment of hydrogeological section I from deposit documentation (direction $\mathrm{W}-\mathrm{E}$ ), shown in Fig. 3.

The layers collapse at a slight angle towards the west. Stratigraphically, the productive Carboniferous formations are represented by the Saddlestone (group 500), Poręba (group 600) and Jakłowiec (group 700) strata. Saddle layers occur only in the near-surface layer of the rock mass and there are no economically significant coal seams in the area. Figure 2 fragment of a map of overburden from the area of the Głowacki and Kościuszko shafts from hydrogeological documentation of the RydultowyAnna coal deposit [19].

The coal seams occurring within the Poręba strata series are characterized by considerable variability in terms of their formation and thickness (from several $\mathrm{cm}$ to about $2.5 \mathrm{~m}$ ). The bedrock of the Poręba strata is claystone, siltstone and fine-grained sandstone. The coal beds within the Jaklowiec strata also show large variability in thickness - from several $\mathrm{cm}$ to about $4 \mathrm{~m}$. The bedrock consists of claystones and siltstones interlayered with sandstones.

The Carboniferous formations in the subsoil of the Głowacki and Kościuszko shaft area are not tectonically disturbed. Further away from this point, the dominant faults named Kolejowy and Rydułtowski III are located. Both faults run approximately parallel in the $\mathrm{W}-\mathrm{E}$ direction. The distance between them oscillates around $2 \mathrm{~km}$.

The Kolejowy fault has a variable discharge. Its amplitude is the highest in the eastern part and amounts to about $180 \mathrm{~m}$. The fault throws Carboniferous strata in a northerly direction. Towards the east the amplitude of the fault throw decreases to about $40-50 \mathrm{~m}$. In the area to the south of the Kolejowy fault the Rydultowy III fault passes, shedding Carboniferous strata to the south about $30-70 \mathrm{~m}$. The Kolejowy fault (to the north) and Rydultowy III fault (to the south) cause that Carboniferous formations lying between them form a structure of a significantly varying degree of elevation in relation to neighbouring areas. Within this structure, the disturbance of the Carboniferous strata is represented only by faults of small 
amplitude of discharge $(<10 \mathrm{~m})$. All areas planned for mining are located in the area of cut-off (between faults). This is also where longwall VIII E-E1 and the testing ground MUSE2.2 are located.

The study area is located in the drainage basin of the Niedobczyce stream, a tributary of the Nacyna River, and further on the Ruda River and the Odra River. The Quaternary aquifer is associated with failing sand and gravel formations. The water table ranges in depth from 0.2 to $20 \mathrm{~m}$. The waters flow freely. In the area of the Głowacki shaft, the Quaternary aquifer does not occur due to the Carboniferous elevation and rainwater, apart from surface runoff into the Niedobczyce stream (Nacyna River) valley, infiltrates into the Carboniferous formations. The Carboniferous aquifer is associated with permeable sandstones within the Saddlestone, Poręba and Jaklowiec strata. These layers are dewatered by mine workings due to the mining activity. There are hydraulic contacts between individual aquifers of the Carbonifer due to, among other things, the presence of faults and mining activities.

\section{Mining - ROW coal mine, mining plant Rydułtowy}

The beginnings of hard coal mining in the Rybnik area date back to the end of the 18th century. Originally, there were several mines operating in the area of the town, including Hoym, Sylwester, Laura or Carolus. In 1936, as a result of a temporary consolidation of smaller mines, the Ignacy mine was established, named after Ignacy Mościcki. In 1968 the Ignacy mine was merged with the neighbouring Rydułtowy mine to the south. The mine has been producing coal for nearly 30 years. In 1995 the liquidation of this part of the Rydultowy mine began.

In the area of the "Głowacki" shaft and the MUSE2.2 polygon mining was carried out from about 1880. The shaft accessed the Poręba strata (group 600) - from seam 602 to seam 620 at a depth of approximately $594 \mathrm{~m}$ below sea level.

Until 1995/6 the following seams were in operation: 602, 604, 606, 607, 608, 613/2, 613/3, 615/1, 615/ $1-2,615 / 2,620 / 1,620 / 1-2$ and 624. The depth of

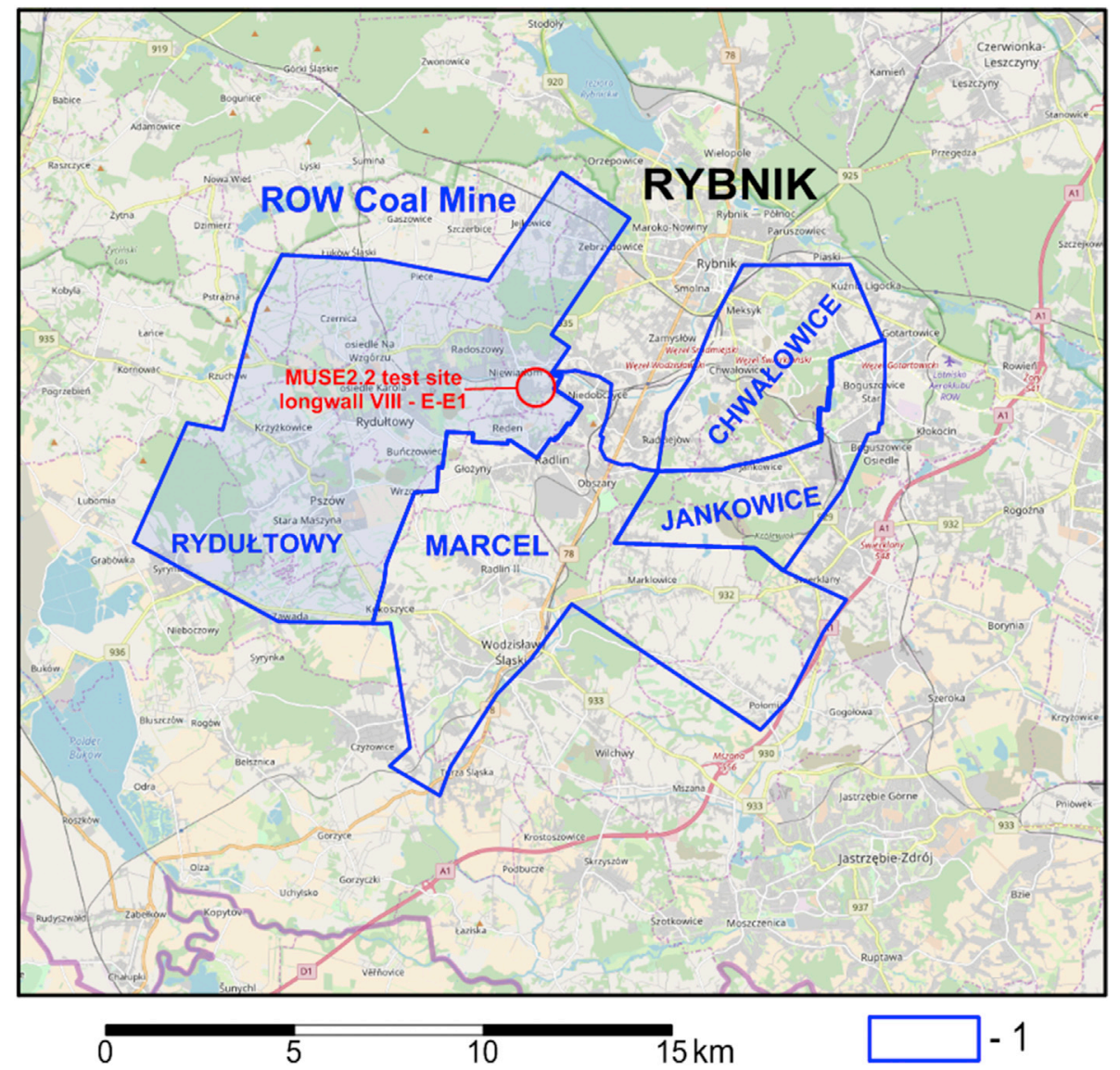

Fig. 1. Location of the MUSE2.2 training ground (longwall VIII E-E1) on the topographic map with location of active mining areas (1) of the ROW Coal Mine Mining Plants - orientation. 
exploitation ranged from approx. 143 to approx. 590 $\mathrm{m}$ below sea level. The exploitation was carried out with a protective pillar around the "Głowacki" and "Kościuszko" shafts. After the liquidation of part of the mine (Ignacy mine) the Głowacki shaft changed its function to ventilation and the Kościuszko shaft was finally liquidated in 2006. After 2000, mining began on the deeper layers of the Jaklowiec strata: 703/1, 705/2-3, 706 707/1, 707/2, 708, 713/1-2 lying in this area at a depth of up to approximately $1140 \mathrm{~m}$. In 2016-2019, ROW Coal Mine, Mining Plant Rydultowy conducted mining operations south-east of the "Głowacki" shaft using the longwalls: II - E1 seam 713/1-2 2017, III - E1 seam 713/ 1-2 2018, IV -E1 seam 713/1-2 2019, IV - E1 seam 706 2017, V - E1 seam 706 2018, VI - E1 seam 706 2019, VIII - E1 seam 703/1 2016, IX - E1 seam 703/1 2017, X - E1 seam 703/1 2018, XI - E1 seam 703/1 2019 and on the eastern side of the shaft with the longwall VII - E-E1 seam 703/1 2016-2017 and the longwall VIII - E-E1 seam 703/1 2019-2020 being surveyed.

Exploitation of longwall VIII - E-E1 commenced on February 20th, 2019 at a depth of approximately
$900 \mathrm{~m}$ below ground level in the northern part of the study area. The average mining depth oscillated around $1000 \mathrm{~m}$. The longwall progressed in a southwesterly direction with a $200 \mathrm{~m}$ wide front until January 1st 2020. The time progression of the longwall is illustrated in Fig. 4. After the coal seam had been extracted at a distance of approximately $780 \mathrm{~m}$, the longwall progress was terminated due to the designated zone of extreme rockburst hazard. The thickness of the mined coal seam 703/1 increased from north to south and ranged from about $1.20 \mathrm{~m}$ to nearly $2.0 \mathrm{~m}$. The 703/1 seam with SW-NE extension collapsed approximately $\mathrm{NW}$ at a slight angle varying between 3 and $12^{\circ}$.

\section{Observation field and testing methodology}

The MUSE2.2 training ground is a rectangular area of $400 \times 1200 \mathrm{~m}$ in size covering the area approximately bounded by Młyńska and Bolesława Śmiałego Streets in the south and Racławicka and Zygmunta Starego Streets in Rybnik-Niewiadom in the north (Fig. 5). The $100 \times 100 \mathrm{~m}$ gravimetric grid included 56 fixed, invariant points. The points were set and

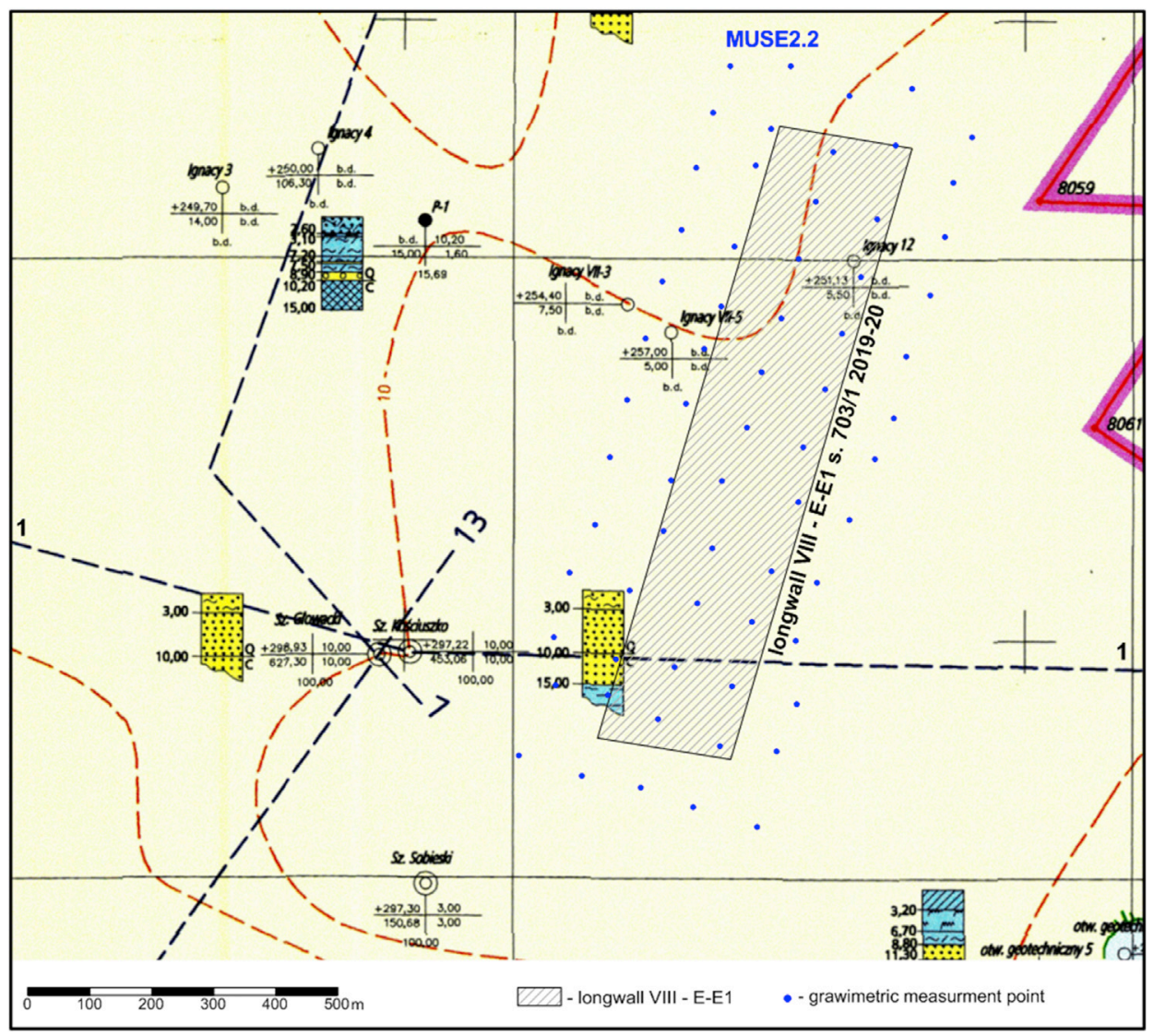

Fig. 2. Fragment of the map of the overburden (Quaternary) from the area of the Gtowacki and Kościuszko shafts from the hydrogeological documentation of the Rydultowy-Anna coal deposit [15], with the marked longwall VIII - E-E1 and measurement points of the MUSE2.2 polygon. 
stabilised in the field so that they overlapped with wall VIII - E-E1 and extended beyond its projection for an area of approximately $100-200 \mathrm{~m}$ in each direction. On the western side, the first two lines of points are located over the eastern part of longwall VII - E-E1, which was exploited in 2016-2017.

A total of six series of measurements of the relative value of the gravity $g$ were performed on the MUSE2.2 testing ground. The measurement series were performed at approximately semi-annual intervals - in spring and autumn in the years 2018-2020. The exact timing of the measurements with reference to the progress of longwall VIII is summarised in Table 1.

The gravimetric field measurements were carried out using the intermediate point method, in which daily measurement sequences were tied to a local base point located about $700 \mathrm{~m}$ south-west of the centre of the training ground. This point (No. 905) is located in the area of the historic Ignacy mine and is stabilised on the foundation of the hoisting machinery of the Głowacki shaft.

The gravimetric observations were made with a modern gravimeter from the Canadian company Scintrex CG-6 Autograv with serial number 18040086. The CG- 6 gravimeter is characterised by a very small yet linear residual drift $(<0.020 \mathrm{mGal} /$ day), which was eliminated during data processing. This instrument enables measurements with a reading resolution of $0.0001 \mathrm{mGal}$ and a repeatability of results of $\pm 0.005 \mathrm{mGal}$. The average error of a single measurement defined as the quotient of the standard deviation of a series of samples and the root of the number of samples $N$ in the series: $\mathrm{SErr}=\mathrm{SDev} / \sqrt{ } N$ in the individual measurement series are summarised in Table 2.

\section{Analysis of the results of time-dependent changes in the gravity field over longwall VIII - E-E1 and their interpretation}

The results of gravimetric measurements in individual series are presented in the form of time-difference maps of $g$ superimposed on the progress map of longwall VIII - E-E1 (Fig. 6). In the maps of changes in the distribution of $g$, cold colours (violet and blue) mark places of negative changes in the field values and warm colours (from yellow to red) mark regions where $g$ values increased. The green colour indicates approximately no change in the relative gravity value between the considered measurement series and the bold, dashed, shaded line indicates the zero isoline of the change in the relative gravity value. Areas so marked may account for

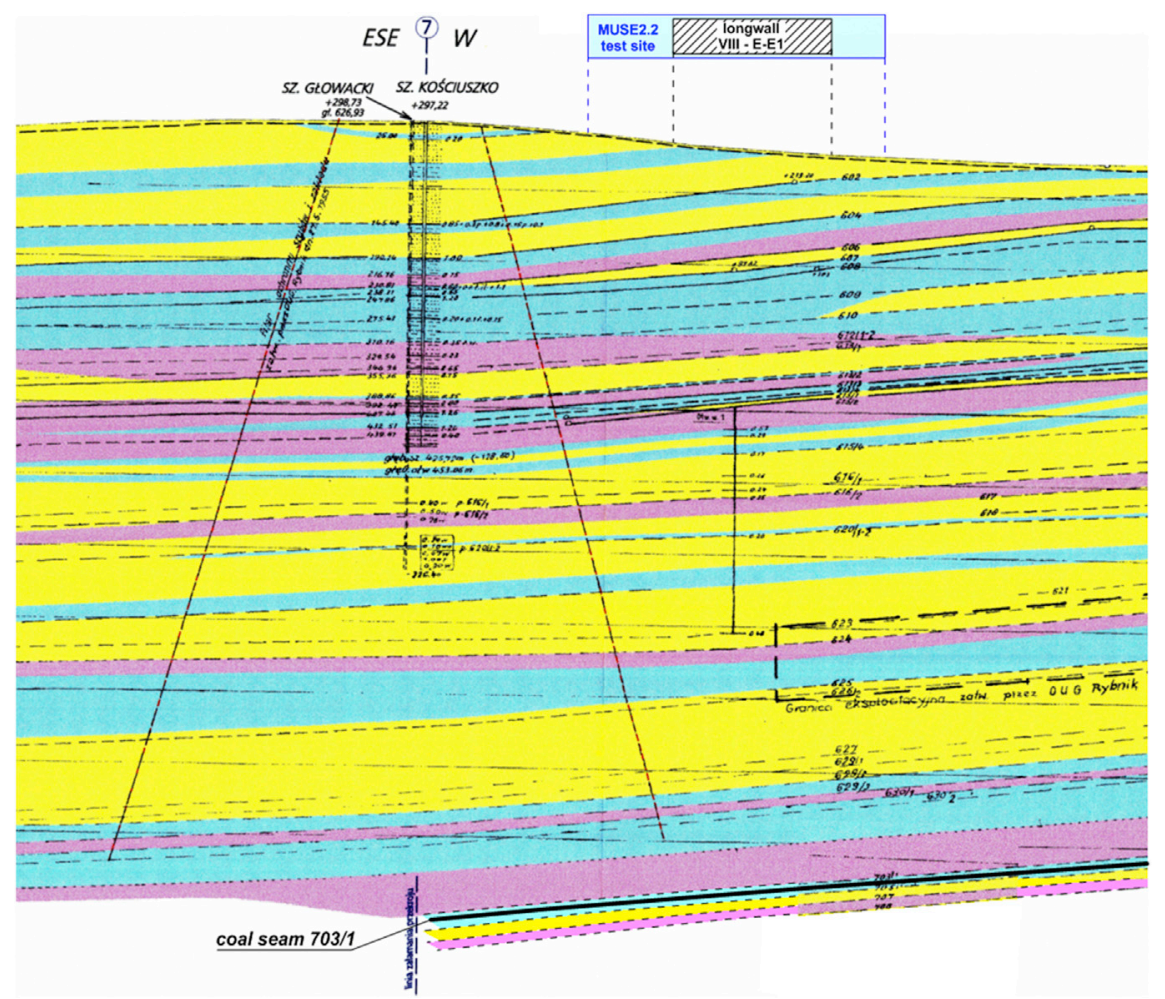

Fig. 3. Fragment of hydrogeological cross-section 1-1 from the area of the Gtowacki and Kościuszko shafts from hydrogeological documentation of the Rydultowy-Anna coal deposit [15], with marked range of the MUSE2.2 polygon and longwall VIII - E-E1. 


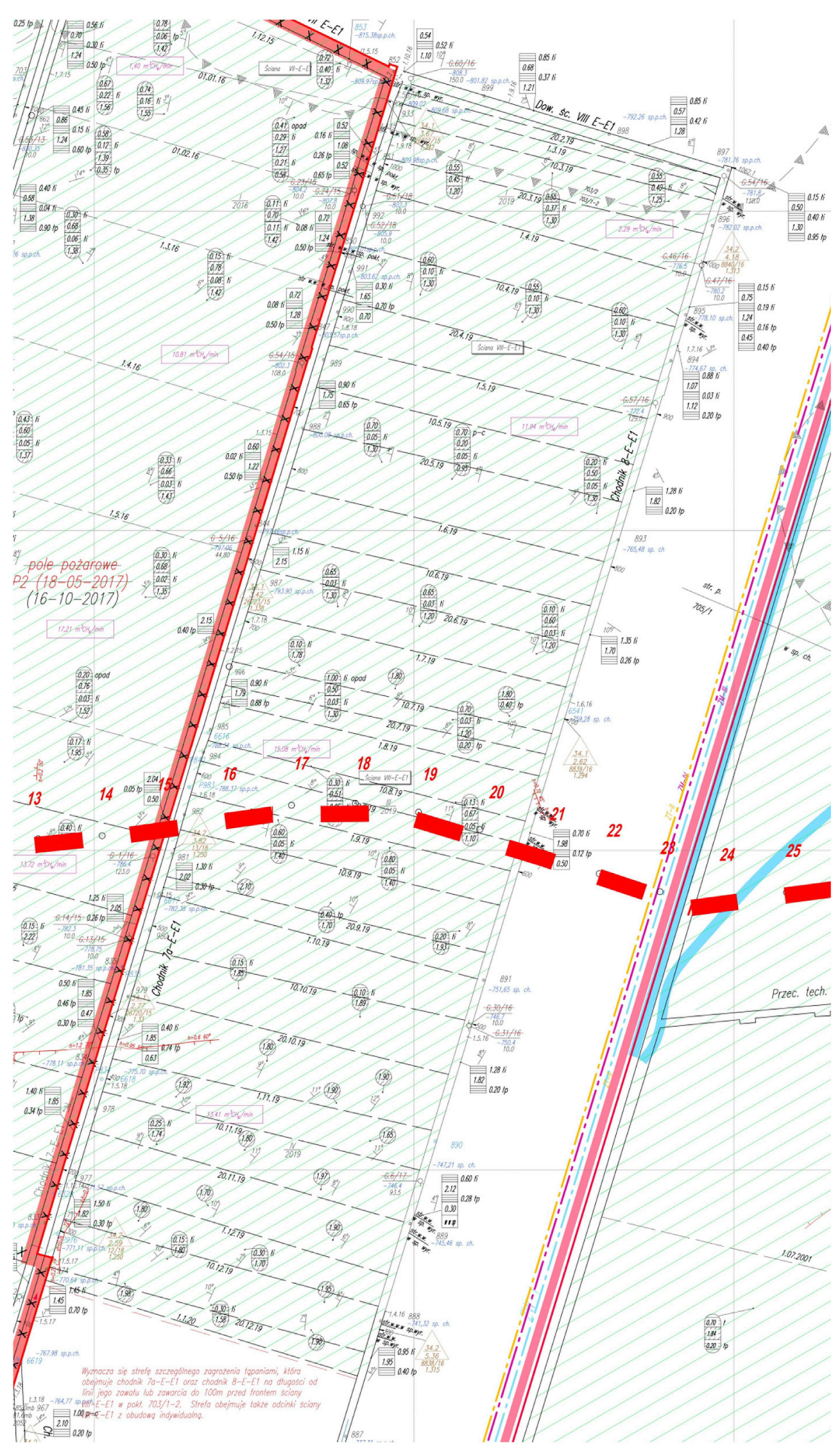

Fig. 4. Progress of mining on longwall VIII - E-E1 in seam 703/1 in the period 2019-2020 according to. Maps of mine excavations p. 703/1-2 and 703/2 ROW Coal Mine, Mining Plant Ryduttowy together with geodetic records for monitoring of subsidence (items 13-25). 
the relatively stable (showing no density changes) state of the rock mass in the area.

After studying the collected data, the series marked II was adopted as the initial reference series, the measurements of which were carried out in autumn 2018, i.e. four months before the start of the longwall operation. Series I (spring 2018) should be considered as an initial reconnaissance series, in which an older measuring instrument, the Scintrex CG-5 gravimeter (no. 40643) operated at Central Mining Institute (GIG) since 2009, was used to carry out the measurements. In order to avoid a possible influence on the results caused by the change of the measuring instrument into dedicated gravimeter of the EPOS-PL project - Scintrex CG-6, in the further differential analysis series I was omitted.

From the point of view of comparative analysis of the obtained distributions of gravity field from particular measurement series, the most significant

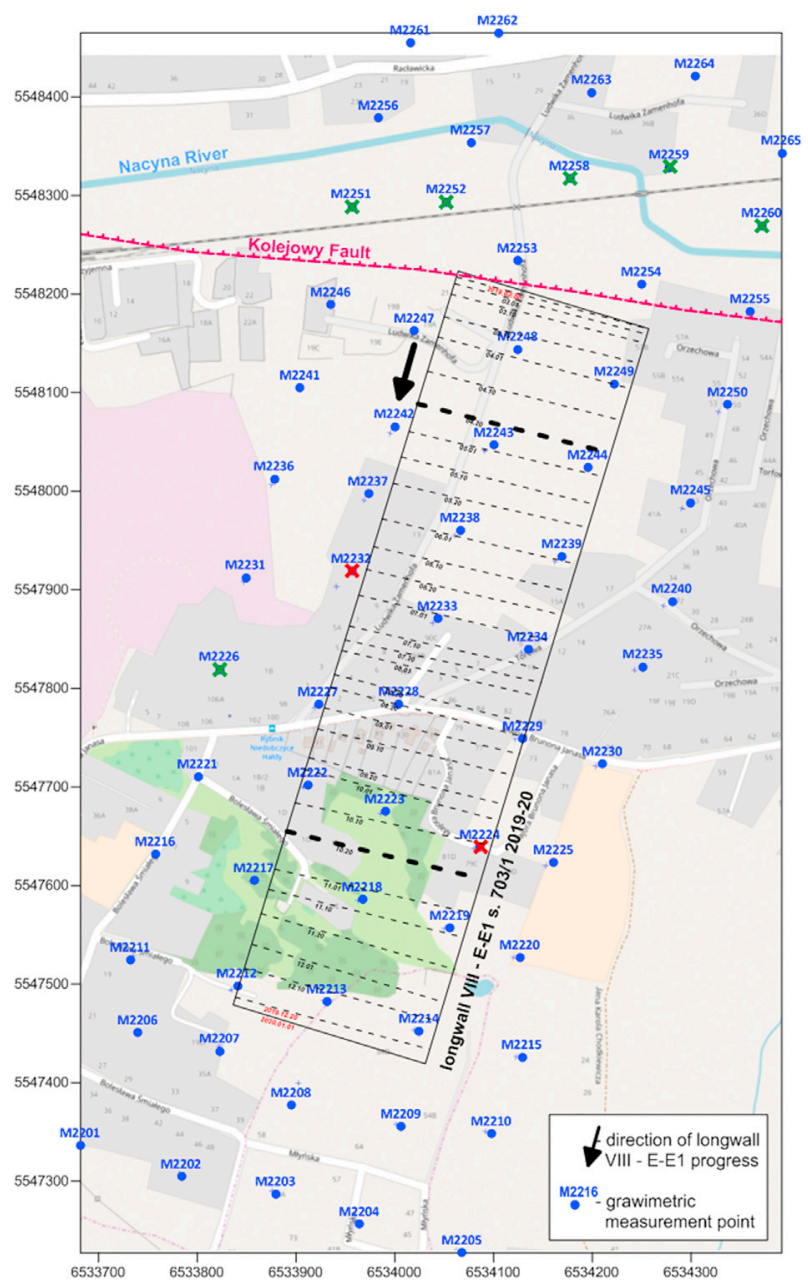

Fig. 5. Location of gravimetric survey points on the MUSE2.2 training ground together with the projection of longwall VIII -E-E1 on the ground surface. seems to be the comparison of series III-II, i.e. analysis of the condition after two months from the commencement of the longwall exploitation (Table 1), as well as IV-II and possibly IV-III. The latter two cases allowed comparison of the state of the rock mass during mining 8 months after the start of mining and two months before the end. Because of the possible influence of seasonal fluctuations of the groundwater table surface (hydrology), it would be appropriate to compare series IV-II (autumn 2019 minus autumn 2018) and VI-II (autumn 2020 minus autumn 2018) and possibly IV-III (autumn minus spring 2019) expecting the possibility of some perturbation of the results in the latter case.

The image of differential anomalies of the gravity field observed approximately four months after the commencement of longwall exploitation, after the III series of measurements $\left(g_{\mathrm{III}}-g_{\mathrm{II}}\right.$ Fig. 6a) is quite homogenous and the changes of values in comparison with the reference series (II) are very slight. The difference level oscillates in the range from -0.014 to $0.033 \mathrm{mGal}$ (amplitude $0.047 \mathrm{mGal}$ ) and indicates a relatively stable - undisturbed state of the rock mass. The rock formation which forms the overburden and surrounds the exploited seam has not yet fully responded to the longwall front condensation.

Starting from the IV series of measurements made about 10 months after the commencement of the longwall exploitation, a density disturbance of the medium is observed, which is revealed in the form of negative and positive anomalies of differential distribution of gravity in relation to series II (Fig. 6b). The general nature of the changes in the distribution of the gravity field at this stage of the longwall progression is similar but the stronger density variation is slightly more evident in the differential anomaly map of series IV related to series III (Fig. 6c).

The differential anomaly values reach extreme values from -0.101 to $0.054 \mathrm{mGal}$ (amplitude 0.154 $\mathrm{mGal}$ ) with a clear shift towards negative values. Negative anomalous zones are concentrated near the Kolejowy fault plane to the north and just in front of the longwall front to the south, as well as slightly further away to the $S$. The zone of elevated differential $g$ values lies practically exactly in the range of depleted goafs of longwall VIII at the time of the IV measurement series (Fig. 6b,c). The maximum values of changes are concentrated around points M2242, M2236, M2237 and for series III they continue in a belt further east to point M2243 and M2244 reaching point M2240.

The picture of differential changes deepens strongly in the next V measurement series (Fig. 6d) 
Table 1. MUSE2.2 measurement series data.

\begin{tabular}{|c|c|c|}
\hline $\begin{array}{l}\text { Measuring } \\
\text { series no. }\end{array}$ & $\begin{array}{c}\text { Date of the } \\
\text { measurements }\end{array}$ & Reference to progress of longwall VIII - E-E1 \\
\hline II & $\begin{array}{l}\text { May } 16-28 \text {, } \\
2018\end{array}$ & $<$ nine months after the start of operation \\
\hline II & $\begin{array}{c}\text { Oct } 15-18, \\
2018\end{array}$ & $<$ four months after the start of operation \\
\hline III & $\begin{array}{l}\text { Apr 24-26, } \\
2019\end{array}$ & during operation: two months after commencement \\
\hline IV & $\begin{array}{l}\text { Oct } 15-28, \\
2019\end{array}$ & $\begin{array}{l}\text { during operation: eight months after commencement and two } \\
\text { months until completion }\end{array}$ \\
\hline $\mathrm{V}$ & $\begin{array}{l}\text { June } 24-29 \text {, } \\
\qquad 2020\end{array}$ & $>$ six months after completion of operation \\
\hline VI & $\begin{array}{l}\text { Nov } 5-13 \text {, } \\
2020\end{array}$ & $>11$ months after completion of operation \\
\hline
\end{tabular}

made six months after the end of longwall exploitation. The anomaly values in the density growth zone from Fig. $6 \mathrm{~b}$ and $c$ have strengthened significantly and expanded in the eastern and southern directions. The range of variation of $g$ is between -0.017 and $0.094 \mathrm{mGal}$ (amplitude $0.111 \mathrm{mGal}$ ) and is significantly shifted in the positive direction. Positive maximum values occur at points M2236, M2237, M2241, M2242 and oscillate between 0.083 and $0.094 \mathrm{mGal}$. The extremity of this zone at point M2236 lies directly above the fire field in seam 703/1 detected in May 2016 during mining of the seam with the previous longwall VII - E-E1 (Fig. 4). The area of compaction of the rock mass above the longwall, marked in red, corresponds to the increase of stresses and their persistence at a high level in the rock mass after the longwall has passed. An isoline of zero change in $g$ relative to the initial series is now visible in the north and southern corners of the map. This means that the impact of mining on longwall VIII already extends far (200-250 $\mathrm{m}$ in the $\mathrm{N}-\mathrm{S}$ axis) beyond its projection on the ground surface. The zone of stress increase does not include the extreme northern (initial) and southern (final) part of the longwall. This may be related to a different deformation response of the rock mass to the passage of the longwall due to different geological-mining conditions in the central part of the longwall as compared to the outer parts (mining carried out within a tectonic rift - Section 2. Geological structure, tectonics and hydrogeological conditions).

Figure 7a summarizes the differential map of twoyear changes in gravity between the VI series of gravity measurements taken in November 2020 and the November 2018 reference series II, together with the location of 466 seismic tremors with energy $>10^{4} \mathrm{~J}$ from the period Feb 26th, 2019-Oct 14th, 2019. This series of measurements was taken approximately 11 months after the longwall was completed. The interval of variability of $g_{\mathrm{VI}}-g_{\mathrm{II}}$ is determined by the values -0.012 and $0.093 \mathrm{mGal}$ (amplitude $0.093 \mathrm{mGal}$ ) and thus very close to the $\mathrm{V}-\mathrm{II}$ series, which translates into a relatively small correction in the picture of the anomaly distribution in Fig. 7a. The values of positive anomalies are almost identical with those of $g_{\mathrm{V}}-g_{\mathrm{II}}$, which may indicate a still high state of stress in the rock mass in this part of the longwall, but at the same time a halt in its strongly increasing tendency.

In series VI-II, with respect to $\mathrm{V}$, differential values in relation to the reference series increase only in the southern part of the region and the extreme of the positive anomaly near point M2236 was displaced ca. $170 \mathrm{~m}$ southwards towards the longwall face. In the north, the zone of densities (positive anomalies) did not change and at the very northern end of the gravimetric monitoring area, the negative anomalies strengthened. The negative anomaly near point M2218, which had been forming since the IV measurement series, also intensified. The presence of these two disturbed zones close together led to the formation of a significant gradient of differential $g$ values between points M2227 and M2218. It indicates the presence of a zone of step change in the density of the medium and the danger of stress accumulation. There was a risk of their sudden discharge in the form of

Table 2. Mean value of the measurement error in gravimetric measurement series I-VI.

\begin{tabular}{|c|c|c|c|c|c|c|}
\hline$\overline{\text { series }}$ & I & II & III & IV & $\mathrm{V}$ & VI \\
\hline date & May 2018 & Oct 2018 & Apr 2019 & Oct 2019 & June 2020 & Nov 2020 \\
\hline SErr av. [mGal] & 0.00476 & 0.00489 & 0.00479 & 0.00350 & 0.00374 & 0.00541 \\
\hline
\end{tabular}


seismic tremors in the area. On the progress map of longwall VIII (Fig. 4), an area of significant rockburst hazard was marked here and mining was discontinued.

The positive anomalous area (isoline +0.04 $\mathrm{mGal}$ ) extends on the differential map between series VI and II much further south reaching here the front of the longwall stopped in January 2020 and in the south-east overtaking it by about $200 \mathrm{~m}$. The whole zone of positive differential anomalies covers almost the entire extent of the exploited seam with longwall VIII with a shift to the south in
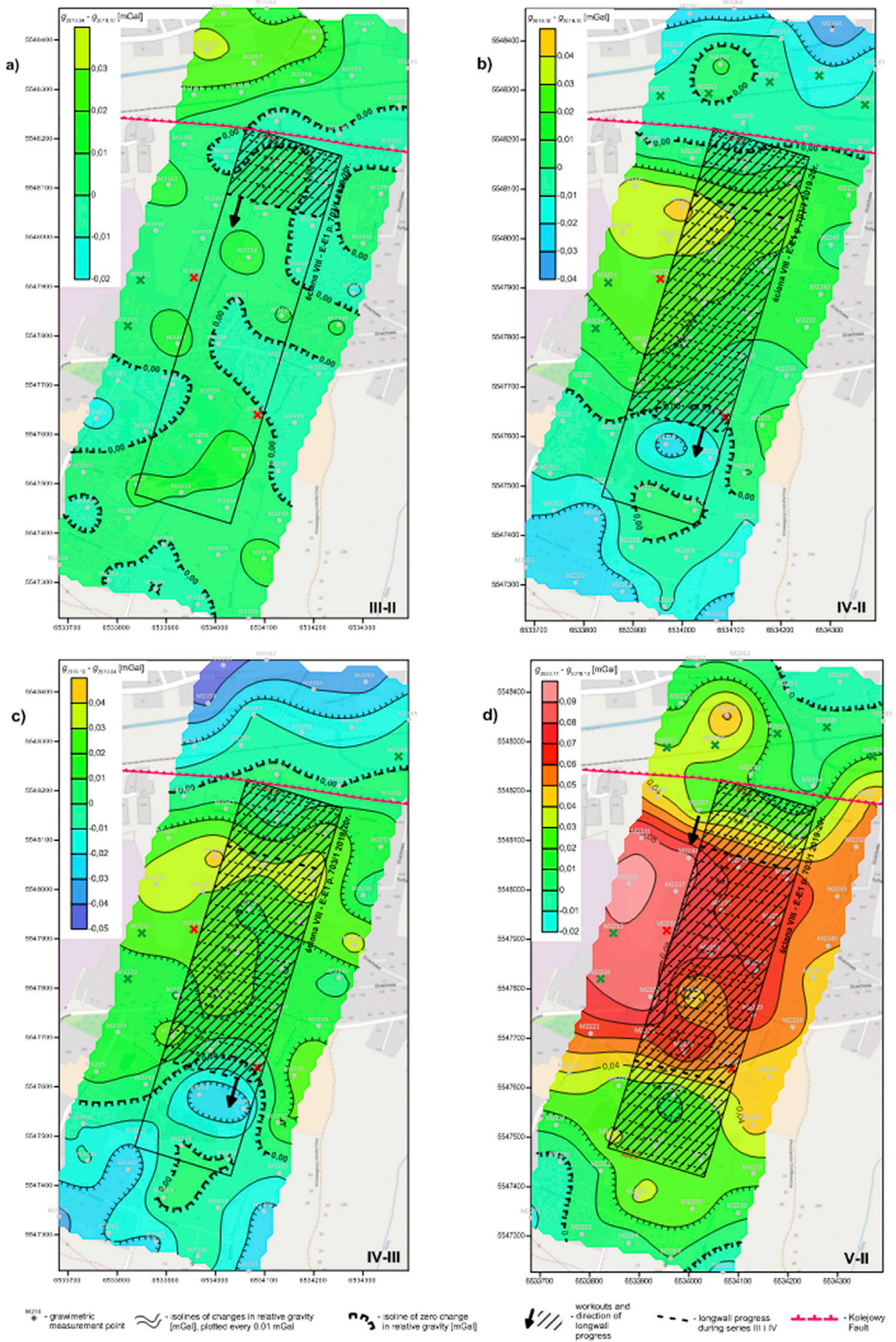

Fig. 6. Differential maps of changes in the gravity field over the exploited longwall VIII - E-E1 at the MUSE2.2 training ground in the periods: a) Oct 2018-Apr 2019; b) Oct 2018-Oct 2019; c) Apr 2019-Oct 2019; d) Oct 2018-June 2020. 
relation to the previous series. The exception is a strong negative anomaly around point M2218, the origin of which may be related to the density dilution of the overburden of the longwall (zone of the forming collapse debris within the overburden) caused by the relaxation of the rock mass after a series of seismic tremors which took place here during the longwall exploitation and are visible on Fig. 7 a.

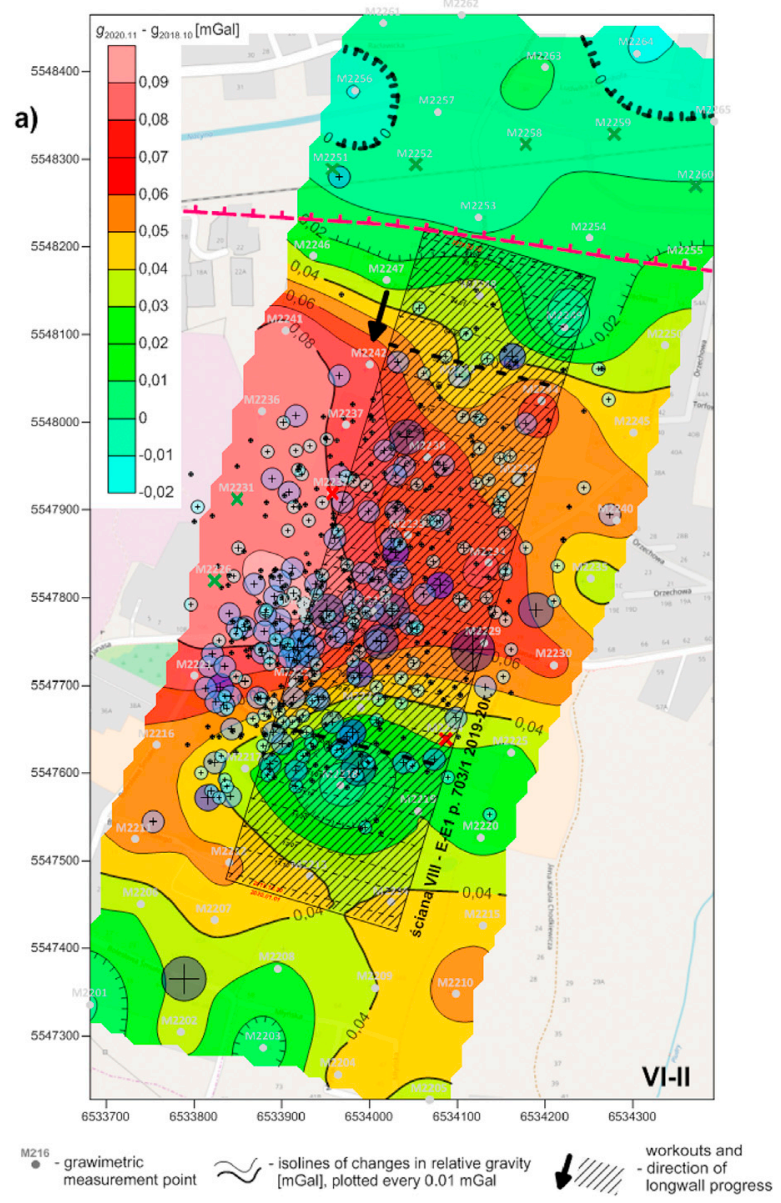

Analysing Fig. $7 \mathrm{a}$, it can be further noted that, with a few exceptions, the epicentres of almost all of the 466 tremors with energies $>10^{4} \mathrm{~J}$ recorded during the longwall operation (Feb 26th, 2019-Oct 14th, 2019) lie within the positive zone of differential anomalies, which is marked by the isoline of the change $g_{\mathrm{VI}}-g_{\mathrm{II}}+0.04 \mathrm{mGal}$. Thus, the tremors occurred in the zone where, in series VI, a progressive compaction of the rock mass from series IV

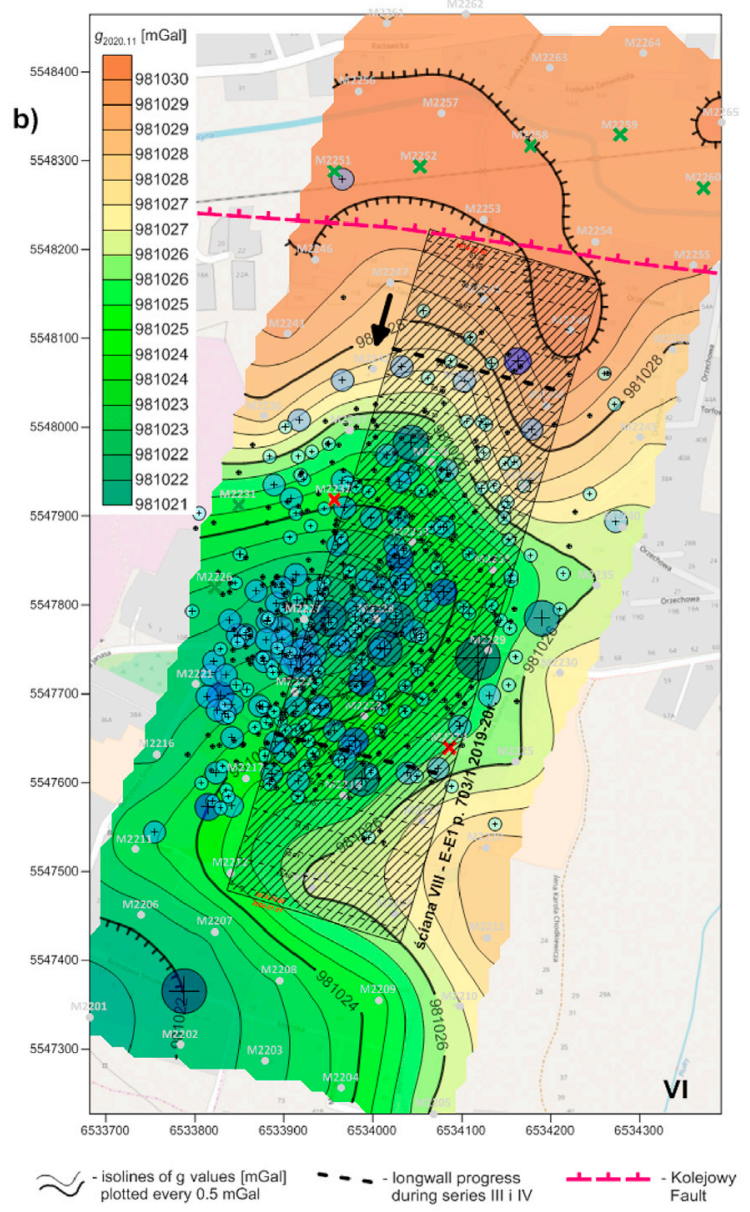

\begin{tabular}{cccccc} 
>=Min. & $<$ Max. & $\%$ & Count & Symbol & Size \\
\hline 10000 & 250000 & 51.5 & 240 & $0.1 \mathrm{~cm}$ \\
25000 & 500000 & 28.1 & 131 & $0.3 \mathrm{~cm}$ \\
50000 & 100000 & 17.0 & 79 & $0.5 \mathrm{~cm}$ \\
100000 & 500000 & 1.5 & 7 & $0.6 \mathrm{~cm}$ \\
500000 & 1000000 & 1.5 & 7 & $0.8 \mathrm{~cm}$ \\
1000000 & 6399000 & 0.4 & 2 & $1.0 \mathrm{~cm}$
\end{tabular}

Fig. 7. Seismic tremors (466) with energy $>10^{4} \mathrm{~J}$ from the period Feb 26th, 2019-Oct 14th, 2019 on the background of the map a) - differential changes of the gravity field over the exploited longwall VIII - E-E1 at the MUSE2.2 training ground in the period Oct $2018-$ Nov 2020 (11 months after completion) and b) - distribution of the gravity field according to measurements of the VI series from November 2020. 
and an increase and persistence of increased stresses were revealed. Those tremors that lie outside the compaction zone are in the region of the strong gradient of $g$ values mentioned earlier.

Figure $7 \mathrm{~b}$ shows as a supplement to the analysis the distribution of the gravity value $g$ itself as of November 2020. It can be noted that the seismic tremors occurred in the zone of the lowest $g$ values, i.e. where there are locally formations with the lowest volumetric density in the ground. This does not contradict the previous considerations because so far the analysis has concerned maps of the distribution of differential anomalies - independent of the measured values of gravity in a single series. The analysis of comparison of the distribution of foci and tremors energy with the distribution of the $g$ field (Fig. $7 b$ ) leads to the conclusion that seismic events occurred in the region of locally lowest values of $g$ caused by reduced density of the medium. It may be due to the transformation of the overburden of the coal seam by earlier exploitation of longwall VII as a result of the fires of May and October 2017. The fire fields from the seam map (Fig. 4) coincide approximately with the range of the lowest $g$ values marked in green in Fig. $7 \mathrm{~b}$. These transformed zones became denser during the progress of wall VIII and in the subsequent series of gravimetric measurements, under the influence of the pressure of the overlying layers, and thus the differential $g$ values in this previously loosened region increased. This trend is likely to continue until the rock mass stabilises and the trend of subsidence and deformation of the medium slows down.

Returning to the differential analyses, it should be noted that during the gravimetric measurements of the VI series, 11 months after the end of mining, the zone of positive $g$ changes continues to expand its range while moving southwards "following the longwall front". This movement is considerably delayed relative to the progress of the longwall because it is likely to take that long for the rock mass to respond to the change in mass distribution due to the extraction of the coal seam. The isoline of zero differential change of $g$ is again visible from the north, which suggests that the rock mass is striving to normalise the stress state and in some time it will undergo relative stabilisation, i.e. reach the state of stress equilibrium which should result in gradual disappearance of seismic activity in this region.

\section{Conclusions}

Underground mining of longwall VIII - E-E1 carried out in the period 2019-2020 has caused volumetric changes in the rock mass. As the longwall progressed, there was a gradual increase in stresses in the overburden, leading to an increase in the density of this part of the rock mass in relation to its surroundings. Densification of the rock medium leads to an increase in positive values of differential anomaly $g$ in subsequent measurement series six and 11 months after the end of exploitation in comparison with the series made four months before its beginning.

The research confirms that the area of the rock mass where the accumulation of stresses takes place (the density of the medium increases) generates its own gravitational field. Its intensity depends on the degree of seismic hazard. The intensity of this field is five to 20 times greater than the measurement error in the tests carried out.

The occurrence of positive anomalous regions indicates the accumulation of stresses at this location (Fig. 6d). In the subsequent measurement series, it should be expected that in those places (provided that factors leading to stress discharge, i.e. tremors, rock bursts, etc. occur) the polarity of anomalies will change to negative in relation to the measurement series revealing accumulation of stresses. This is particularly well visible in the southern part of longwall VIII in the VI-II series of measurements (Fig. 7a). The increase in negative anomalies and the accompanying tremors lead to the formation of density relaxation zones, i.e. areas where the rock mass is expanded.

The studies show that the centres of density changes of differential gravity anomalies shift with time in the overburden of longwall VIII towards: old mining goafs, the edge of longwall VIII and partially towards the plane of the Kolejowy fault in the north of the study area.

In conclusion, it should be stated that the gravimetric method of searching for areas of increased and decreased density in the differential variant is completely objective - independent of the subjective attitude of the analyst. The results obtained are interesting especially because the zones of strong density changes correlate with the locations of strong seismic tremors. Since an increase in the differential value corresponds to stress concentration and may precede seismic energy emission from the rock mass in the vicinity of the longwall, the results of the differential analysis could contribute to the prediction of seismic tremors and rock bursts during mining operations. However, this would only become achievable if the measurement series could be performed with a significant time density (i.e. at least every one-three months).

The methodology used in the study made it possible to observe density changes within the 
longwall overburden, which are linked to the evolution of the stress state in the rock mass. An analogous research methodology will be used in the near future on the training ground above the protective pillars of the Marcel coal mine, where multi-seam mining is carried out. The research will be focused on the analysis of the distribution and changes in the state of stresses by means of differential $g$-anomaly analysis obtained in measurement series performed every three months over a period of three years within the EPOS-PL PLUS project.

\section{Conflicts of interest}

None declared.

\section{Ethical statement}

The author states that the research was conducted according to ethical standards.

\section{Funding body}

The work was conducted within the project called EPOS-PL - European Plate Observing System. The project is funded under the Intelligent Development Operational Programme 2014-2020 and co-financed by the European Union from the European Regional Development Fund (ERDF). Project Number: POIR.04.02.00-14-A003/16-00.

\section{References}

[1] Stec K. Aktywność sejsmiczna Górnośląskiego Zagłębia Węglowego - 30 lat ciągłej obserwacji przez Górnośląska Regionalną Sieć Sejsmologiczną. Katowice: Przegląd Górniczy; 2007. p. 14-22. nr 7- 8/2007.

[2] Marcak H, Mutke G. Seismic activation of tectonic stresses by mining. J Seismol 2013;17(4):1139-48.

[3] Dubiński J, Stec K, Bukowska M. Geomechanical and tectonophysical conditions of mining-induced seismicity in the Upper Silesian Coal Basin in Poland: a case study. Arch Min Sci 2019;64(1):163-80.
[4] Kotyrba A, Kowalski A. Linear discontinuous deformation of A4 highway within mining area "Halemba." Miner Resour Manag 2009;25(3):303-18.

[5] Kowalski A, Jędrzejec E, Gruchlik P. Linear discontinuities deformations of the surface in the upper silesian Coal Basin. Arch Min Sci 2010;55(2):331-46.

[6] Kowalski A. Deformacje powierzchni na terenach górniczych kopalń węgla kamiennego. Katowice: Główny Instytut Górnictwa; 2020.

[7] Strzałkowski P, Ścigała R. The causes of mining induced ground steps. Case study from Upper Silesia in Poland. Acta Geodyn Geomater 2017;14(3):305-12.

[8] Strzałkowski P, Szafulera K. Occurrence of linear discontinuous deformations in Upper Silesia (Poland) in conditions of intensive mining extraction-case Study. Energies 2020;13(8): 1897.

[9] Fajklewicz Z. Grawimetria stosowana. Kraków: Uczelniane Wydawnictwa Naukowo- Dydaktyczne AGH; 2007.

[10] Allis RG, Hunt TM. Analysis of exploitation-induced gravity changes at wairakei geothermal field. Geophysics 1986;51(8): 1647-60.

[11] Geri G, Marson I, Rossi A, Toro B. Crustal deformation and gravity changes during the first ten years of exploitation of the new Travale-Radicondoli geothermal field, Italy. Geothermics 1985;14. 2/3 Conference (United States).

[12] Zheng-Xin L, Hui L. Earthquake-related gravity field changes at Beijing-Tangshan gravimetric network during 1987-1998. Studia Geophys Geod 2009;53(2):185-97.

[13] Kazama Takahito, Tamura Yoshiaki, Asari Kazuyoshi. Seiji Manabe \& Shuhei Okubo Gravity changes associated with variations in local land-water distributions: observations and hydrological modeling at Isawa Fan, northern Japan. Earth Planets Space 2012;64:309-31.

[14] Kotyrba A, Balicki A, Kortas Ł. Zmiany regionalnego pola grawitacji w północnej części Górnośląskiego Zagłębia Węglowego w latach 2002-2003vol. 53. Warszawa: Przegląd Geologiczny Tom; 2005. p. 299-305. 4.

[15] Kotyrba A. Czasowe zmiany pola siły ciężkości w Górnośląskim Zagłębiu Węglowym i ich związek z eksploatacja górniczą5. Przegląd Górniczy; 2014. p. 48-57.

[16] Fajklewicz Z. Mikrograwimetria górnicza, Wyd. Śląsk. Katowice; 1980.

[17] Mutke G, Kotyrba A, Lurka A, Olszewska D, Dykowski P, Borkowski A, et al. Upper silesian geophysical observation system - a unit of the EPOS project. J Sustain Mining 2019; 18(4):198-207.

[18] Sośnica K, Rohm W, Bosy J, Zajdel R, Hadas T, Kapłon J, et al. Monitoring of Earth surface displacements using integrated multi-GNSS, gravity, seismic, and InSAR data in the framework of GGOS-PL++. In: 42nd COSPAR scientific assembly. Held 14-22 July pasadena, CA, USA; 2018. Abstract id. B2. 1-37-18.

[19] Dokumentacja hydrogeologiczna określająca warunki hydrogeologiczne $\mathrm{w}$ związku $\mathrm{z}$ zamierzonym wykorzystaniem odwodnień w celu wydobywania kopaliny ze złoża węgla kamiennego „Rydułtowy” wg stanu na 01.01.2012. Zakład Geologii i Geofizyki GIG; czerwiec 2012. 